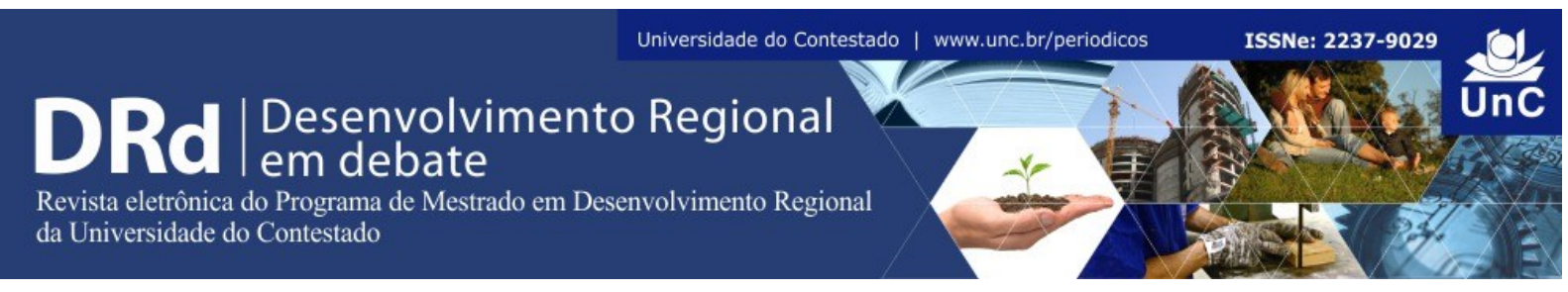

\title{
REPERCUSSÕES TERRITORIAIS DOS INVESTIMENTOS EM CULTURA NA REGIÃO “ROTA MISSÕES" DO RIO GRANDE DO SUL
}

\author{
Victor da Silva Oliveira ${ }^{1}$ \\ Tiago Costa Martins ${ }^{2}$
}

\begin{abstract}
RESUMO
O presente artigo, fazendo uso de resultados da pesquisa realizada em 2014 intitulada "A alocação de recursos públicos e a possibilidade de configuração de um arranjo produtivo da cultura regional: a 'Rota Missões' no Rio Grande do Sul”, tem por objetivo discutir as repercussões territoriais a partir dos investimentos públicos municipais em cultura na região das missões do Rio Grande do Sul, Brasil, com base na ampliação do referencial teórico da pesquisa supracitada e em dados oriundos de órgãos oficiais sistematizados a partir de pesquisas anteriores e por propostas dos autores. A análise teórica buscou captar elementos das discussões localistas ponderando sua contribuição em paralelo à percepção de inferências decisivas de outras escalas, sendo realizada, assim, uma análise multiescalar. Os resultados, apresentaram a possibilidade de identificação de padrões no deslocamento dos gastos a partir das categorizações criadas, assim como a percepção de um município polo, Santo Ângelo, que concentra os fluxos referentes a gastos públicos municipais em cultura na região das Missões do Rio Grande do Sul.
\end{abstract}

Palavras-chave: Cultura. Região. Política pública. Territorialização de gastos públicos.

\section{TERRITORIAL REPERCUSSIONS OF INVESTMENTS IN IN THE REGION “ROTA MISSÕES" OF RIO GRANDE DO SUL}

\begin{abstract}
This article, using the results of research conducted in 2014 entitled "The allocation of public resources and the possibility of setting up a productive arrangement of regional culture: the "Rota Missões" in Rio Grande do Sul", aims to discuss territorial repercussions from the municipal public investment in culture in the region of the Missões of Rio Grande do Sul, Brazil, based on the expansion of the theoretical framework of the aforementioned research and data from official agencies systematized from previous research and proposals of authors. The theoretical analysis sought to capture elements of localistic discussions weighting contribution in parallel to the perception of decisive inferences from other scales being performed, thus, a multiscale analysis. The results showed the patterns of identification

\footnotetext{
${ }^{1}$ Graduado em Geografia (UNIFRA), Mestre em Desenvolvimento Regional (UNISC) e doutorando em Geografia (UFPE). Universidade Federal de Pernambuco (PE). Pernambuco. Brasil. E-mail: victorsoliveira@hotmail.com

2 Doutor em Desenvolvimento Regional pela Universidade de Santa Cruz do Sul. Professor adjunto do curso de Relações Públicas da Universidade Federal do Pampa - Campus São Borja. Rio Grande do Sul. Brasil. E-mail: tiagomartins@unipampa.edu.br
}

DRd - Desenvolvimento Regional em debate (ISSNe 2237-9029)

v. 6, n. 1, p. 136-158, jan./jul. 2016. 
possibility of shifting spending from the established categorization, as well as the perception of a hub municipality, Santo Angelo, which concentrates flows related to municipal spending on culture in the region of the Missões of the Rio Grande do Sul.

Keywords: Culture. Region. Public policy. Territorial public spending.

\section{INTRODUÇÃO}

O presente artigo é parte das reflexões realizadas na pesquisa financiada pelo Ministério da Cultura durante o ano de 2014 intitulada "A alocação de recursos públicos e a possibilidade de configuração de um arranjo produtivo da cultura regional: a 'Rota Missões' no Rio Grande do Sul". Na ocasião, foi objetivado verificar, por meio das ações realizadas pelas prefeituras municipais na região das Missões, o papel das políticas públicas na alavancagem de um arranjo produtivo da/na cultura regional.

Entre os vários objetivos secundários, destacamos um para desenvolver neste artigo. Assim, buscamos aqui discutir as repercussões territoriais a partir dos investimentos públicos municipais em cultura na região das missões do Rio Grande do Sul, Brasil. Para além das repercussões das prefeituras municipais - agente do Estado analisado - da região assinalada, antecedemos a proposta em si deste artigo por uma reflexão sobre alguns determinantes do contexto histórico, político e econômico na aplicação de recursos públicos, seja na opção por setores privilegiados ou por territórios.

Ao mesmo passo, repercutimos o campo aberto para novas tendências políticas no Brasil em determinados setores, abrangendo agentes até então marginalizados, da mesma forma que evidenciamos a importância de ações no âmbito da cultura contemplarem uma prática e análise interescalar.

Para realização dessa pesquisa, fazendo uso de um referencial bibliográfico ampliado da pesquisa anteriormente citada. Buscou-se dados secundários junto a órgãos oficiais, como o Tribunal de Conta do Estado do Rio Grande do Sul e da Receita Federal, sistematizando-os a partir de propostas da Fundação de Economia e Estatística e da Federação das Indústrias do Estado do Rio de Janeiro, somando ainda propostas próprias dos autores a fim de elucidar o deslocamento territorial dos gastos em culturas dos municípios da região e identificar padrões de cadeias assim como o (ou 'os') polo(s) no setor na região Rota Missões do Rio Grande do Sul.

\section{REVISÃO HISTÓRICA E CONCEITUAL: CONTEXTUALIZAÇÃO DA ALOCAÇÃO DE RECURSOS PÚBLICOS}

Desde os primeiros ciclos econômicos no Brasil, os investimentos públicos desprendidos pelo Estado, independente da escala de gestão, são alinhados com as ideologias postas no âmbito global e nacional, que aderem na política pública e acabam por delinear os focos setoriais e territoriais do provimento de recursos. 
Nesse tópico, buscamos realizar um breve resgate histórico de determinados períodos históricos da política e da economia brasileira que apontam as transformações produtivas e as definições de alocação de recursos públicos em certos setores e territórios selecionados.

Os mais de quatrocentos anos de surgimento, maturação e consolidação da sociedade agrária brasileira, desde a chegada dos colonizadores portugueses em 1500 até a transição tardia para a sociedade urbano-industrial, em 1930, marcaram a política, a economia e o território nacional com profundas marcas que perduram até os dias atuais.

Segundo Pochmann (2010), as forças politicas e econômicas criadas em torno dos grandes ciclos agrários do país operaram como forças quase exclusivas nas mais diversas esferas nacionais. As repercussões sociais e territoriais foram das mais diversas, porém sem dúvida a grande segregação social e desigualdade territorial entre os poucos núcleos produtores, dominados por uma pequena elite que dialogava intimamente com forças externas, com todo restante do território nacional vivendo a margem de ações do estado que favorecessem suas práticas socioeconômicas.

Durante o período colonial, em que distintos ciclos produtivos ocorreram nos diferentes quadrantes do país, se estruturou, de maneira geral, dois distintos territórios. $\mathrm{O}$ primeiro interligado com o exterior a partir de fluxos produtivos - que se estendiam para as relações sociais e culturais - guarnecidos por grande presença de técnicas modernas e aplicação de recursos públicos e privados. O segundo nicho, caracterizado por se encontrar a margem do primeiro, composto por movimentos de pequena escala produtiva, desde a subsistência até o atendimento de mercados regionais limitados, sem apoio técnico e desassistido pelo poder público.

Territorialmente, se notava pequenos enclaves produtivos, com presença do escravo e crescimento de uma elite agrária que influenciava diretamente nos caminhos políticos e econômicos do país. Em paralelo, se manifestava em grande parte do território o empobrecimento humano de condições econômicas, sociais e esvaziamento político.

No espectro cultural, havia - e ainda há -, por parte da elite branca, a busca por padrões europeus, reproduzidos no seu modo de vida nos enclaves produtivos no Brasil. $\mathrm{O}$ cultivo de produtos para exportação geravam grandes excedentes que, em parte, eram utilizados para manutenção de um padrão de vida estranho ao brasileiro do período, se aproximando de tendências europeias, gerando um lastro entre as pompas da oligarquia e as práticas socioculturais das populações tradicionais, causando com base na diversidade a desigualdade. Não houve, no momento de acumulo de capitais da produção primaria, força política suficiente para utilização dos excedentes para transição para produção manufatureira.

De fato, o contexto internacional, no qual o Brasil se encontrava inserido de forma subordinada, acabou por favorecer a formação de pequenas porções descontinuas do território nacional com produção moderna e presente no grande mercado. O distanciamento geográfico valorizou a diversidade natural e social e dificultou a formação de mercado interno, tornando preponderantes as trocas externas e delineando a alocação de recursos públicos em parcelas específicas do território nacional. A dissolução das "ilhas de modernidade" do Brasil foram discutidas por Oliveira (1981) em seu texto clássico "Elegia para uma re(li)gião", onde o autor debate a integração do mercado interno do Brasil em meados do século XX, afirmando que, em termos econômicos e produtivos, a região no Brasil havia sido superada. 
O período marcado pelo inicio da industrialização no Brasil, que tomou força após 1930, trouxe para o cenário político e econômico do país novas forças com quem a elite agrária passou a dividir espaço. $\mathrm{O}$ 'arranque' da manufatura - que já ocorria anteriormente, porém como menos força - acabou por fortalecer alguns aspectos percebidos durante os ciclos agrários, contudo, evidenciando outro viés político. A integração nacional praticamente inexistente fruto do modelo produtivo empregado nos ciclos agrário do país, fez efervescer a necessidade do que Pochmann (2010) denominou de 'fuga para frente'. Um compromisso assumido pelo Estado brasileiro com objetivo de expandir de forma rápida a produção industrial, integrando nacionalmente o território e substituindo importações.

Celso Furtado (1974) percebe haver a intensificação do processo de imitação dos padrões de consumo das classes mais abastadas da sociedade, voltadas para uma apreciação pelo estrangeiro. Essa relação remete a aceitação do externo como conquista de progresso, ligada a um prestigio social. Essa apreciação é acompanhada sempre de penetração de ideias e valores estrangeiros.

Nas palavras de Furtado (1974, p. 80):

A existência de uma classe dirigente com padrões de consumo similares aos de países onde o nível de acumulação de capital era muito mais alto e impregnado de uma cultura cujo elemento motor é o progresso técnico transformou-se, assim, em fator básico na evolução dos países periféricos.

A transição do Brasil de uma economia agrário-exportadora para a urbano-industrial ocorrera de forma rápida. Os dados do Instituto Brasileiro de Geografia e Estatística mostram que entre 1930 e 1960, pouco mais de três décadas de expansão industrial, a população urbana superou a rural.

Territorialmente, o crescimento das atividades urbanas e de manufatura ocorreu no país localizado nas regiões cafeeiras do sudeste. De acordo com Pochmann (2010) o ciclo do café fora tão expressivo durante o século XIX que permitia a destinação de recursos em pequenas indústrias de foco regional com utilização de trabalho não-escravo. Em anos de dificuldade de importações, a produção interna crescia de importância e abastecia os mercados.

A escala de ação privilegiada foi a nacional. As relações de poder oriundas das políticas estratégicas, as regulamentações e os embates de classes tinham como arena a economia e o sistema político do território nacional.

Os lugares-regiões possuindo papel secundário, acabaram por não ser contemplados em totalidade. A indústria, dentro do território nacional não se difundiu homogeneamente, caracterizando territórios de concentração e construção de regiões industriais com grande especialização em determinados setores, pautados por vantagens comparativas ricardianas, desconsiderando a diversidade dos territórios, em destaque o Brasil com suas dimensões continentais e multiplicidade de faces. Chegou-se a concentrar mais de $60 \%$ da produção industrial apenas no Estado de São Paulo.

Instalada a crise da década de 1980 e outras razões para além do território brasileiro, o estado intervencionais deixa a cena e crescem as concepções liberais juntamente com manobras que levaram a fragmentação das ações nacionais e crescimento de buscas locais por 
alocação de recursos públicos e privados. Hobsbawm (2002) afirma que o Estado, principal agente regulador da economia, já não tinha mais mecanismos eficazes para atender as necessidades da economia mundial.

Em paralelo a efervescência da retomada de políticas de cunho liberal no Brasil, era percebido as crescente reinvindicações por demandas sociais que historicamente foram reprimidas no Brasil, especialmente no período autoritário que se agravou com a crise. As possibilidades abertas com a redemocratização e a Constituição Federal do Brasil, de 1988, colocaram em pauta lutas sociais e trabalhistas que eram destoantes do ideário autoritário de anos anteriores.

O Estado não desapareceu, porém seu papel intervencionais foi substituído pelo fomento na atração de investimentos e facilitação das exportações, elevação das taxas de juros, preparando as regiões selecionadas para o recebimento de grandes empresas que passaram a transitar pelo mundo em busca de locais favoráveis para a produção, que se fragmentou para maximização dos lucros. As empresas globais passaram a agir diretamente no território, aumentando seu poder político e retirando do Estado o poder absoluto do território, privilegiando no período, de acordo com Araújo (2007), as escalas global e local em detrimento do nacional.

O Estado foi diminuído ao passo que crescia a onda liberal que, somada a crise inflacionária, de acordo com Cargnin (2011), forçou o fechamento de instituições planejadoras e desestruturou seu aparato. As privatizações foram postas em frente as questões de cunho territorial, delegando ao Estado apenas a função de sanar questões de sua instalação.

As ações de alocação de recurso do Estado, pautado pelas novas concepções liberais, retoma a preocupação territorial, porém por caminhos distintos dos anteriores. As novas ações estão alinhadas em perceber e direcionar esforços para o mercado, criando as melhores condições em regiões/locais selecionadas para o recebimento das grandes empresas e os investimentos de privatização.

A transformação do modelo neoliberal para a retomada do social-desenvolvimentismo, segundo Pochmann (2010), pode ser percebido nos anos primeiros da década de 2000, especialmente com as políticas voltadas para reestruturar o Estado nacional soberano.

No atual momento, distinto da maior parte da história nacional, o Estado age para a movimentação do mercado de forma não autoritária e não apenas em setores tradicionais. Políticas sociais e de redistribuição de renda possuem importantes rebatimentos econômicos, para além dos sociais. Nesse ponto residem os desafios ao Estado democrático, uma vez que se tem a necessidade de propor e executar propostas desenvolvimentistas e ao mesmo tempo promover a proteção social das minorias.

Territorialmente, crescem as ações que buscam criar oportunidades em espaços desassistidos da ação pública, seja através de investimentos setoriais, como na seguridade social, cultura educação, ou em políticas propriamente regionais-territoriais.

Compreender a alocação dos recursos públicos no território consiste anteriormente de perceber o momento político e econômico em voga não apenas no espaço nacional. Trazendo a análise para a percepção local no caso brasileiro, as três entidades administrativas do território, a União, os Estados e o Município, aplicam recursos segundo concepções que 
extrapolam as relações ideológicas do próprio escopo administrativo. À de se pesar os diferentes montantes aplicados por cada ente, contudo, sem sombra de dúvidas o município representa a aplicação de recurso público em maior diálogo com a realidade local e regional, observando que não necessariamente corresponde os empenhos com maior reflexão técnica.

\subsection{NOVAS TENDÊNCIAS NA POLÍTICA NACIONAL}

No ambiente político mais recente do Brasil tem havido maior espaço para inserção de agendas historicamente desassistidas de políticas públicas, especialmente na escala nacional. A agenda sobre desenvolvimento, por exemplo, esteve sempre pautada e limitada a questões relativas ao incremento produtivo e ampliação do emprego. Abre-se campo para inserção de novas questões estruturantes para uma política de desenvolvimento. Um destes campos é relativo as questões culturais que, apesar de ainda galgar de poucos recursos no ambiente político brasileiro em comparação a outras pastas, vem inserindo pautas que extrapolam a agenda própria da cultura e promovendo políticas abrangendo outros setores.

Para além das questões teóricas, foi buscado discutir brevemente o momento político brasileiro oportuno para novas abordagens, exemplificando com intervenções do Estado em prol de agentes historicamente desassistidos.

A política brasileira recente vem sofrendo transformação ainda resultante da Constituição Federal do Brasil de 1988, citada anteriormente, que ofereceu possibilidade de descentralização política por diversos meios de intervenção estatal antes ausente. Entretanto são duas formas de ação pública que vem chamando atenção devido a seu caráter distinto da tradição brasileira: as abordagens intersetoriais-territoriais; e criação e ampliação de políticas para agentes fragilizados pela estrutura social historicamente construída.

Um bom exemplo da inserção de novos agentes na pauta política brasileira é a criação do Ministério de Política Agrícola e Desenvolvimento Agrário em 1999, ainda no governo Fernando Henrique Cardoso, que, em 2000, passou a denominar Ministério do Desenvolvimento Agrário (MDA). O Brasil historicamente desprendeu esforços para inserção no mercado mundial a partir do seu sistema agrário exportador, desse o pau-brasil, passando pelo açúcar, cacau, café, borracha, soja, enfim. Essa escolha, que se definia por vantagens competitivas e debatidas contrariamente por estruturalistas a partir do pós-Segunda Guerra Mundial, como referido anteriormente, delineou a percepção do espaço rural como meio de produção, preterindo as relações de sociais e de vida para além da atividade agrícola em si.

Contudo, os antecedentes que vieram a trazer para pauta política brasileira a pequena produção e suas ramificações foi pautada por lutas agrárias e a construção de um ambiente democrático que fizessem ingressar nas ações públicas parte do meio agrário tradicionalmente excluído. Especialmente após a redemocratização, a criatividade escera largamente as lutas por uma compreensão distinta do meio rural e pela tutela do Estado as suas reinvindicações que eram distintas das grandes propriedades agropecuárias alinhadas ao mercado internacional. 
Outra ação recente do Estado brasileiro que vem promovendo integração de populações desguarnecidas de ação pública e que contribui para o avanço da integração intersetorial no ambiente político do país é o Programa Território da Cidadania (PTC). O PTC, lançado em 2008, inicialmente abrangendo sessenta territórios que passaram para cento e vinte em 2009, vem provendo ações em todos os entes federados na busca por maior equidade social e regional. Atualmente o programa tem engajamento de dezessete ministérios, quatro secretarias especiais, além da Secretaria Geral da Presidência da República e outros órgãos federais, como Banco do Brasil e Caixa Econômica Federal. No ano de 2009, o programa destinou $\mathrm{R} \$ 23,5$ bilhões aos cento e vinte territórios, promovendo ações planejadas de apoio à produção, cidadania e acesso a direitos e de infraestrutura.

Cabe destacar a proposta diferenciada do Programa ao integrar esforços de diferentes Ministérios, tomando por base de ação o território e não o setor - educação, saúde, infraestrutura, enfim -, os quais são escolhidos a partir de indicadores que privilegiam a intervenção em regiões com populações desprovidas por vários anos de investimentos.

Cabe mencionar outra ação pelo seu caráter distinto que demonstra o momento oportuno de espaço para novas abordagens no ambiente político brasileiro. A Política Nacional de Desenvolvimento Regional que se encontra em sua segunda fase possui entre seus objetivos, segundo o Ministério da Integração, "Sustentar uma trajetória de reversão das desigualdades inter e intrarregionais, valorizando os recursos endógenos e as especificidades culturais, sociais, econômicas e ambientais" e "Criar condições de acesso mais justo e equilibrado aos bens e serviços públicos no território brasileiro, reduzindo as desigualdades de oportunidades vinculadas ao local de nascimento e moradia”.

A Política propõe inserir o corte regional nas ações públicas, fortalecendo as ações intersetoriais e promovendo redução de desigualdades e o desenvolvimento no território brasileiro. Por não possuir recursos próprios para sua efetiva assimilação pelos Ministérios, assim como promover suas próprias intervenções, a proposta ainda padece de diversos limitantes para sua assimilação de forma abrangente. Contudo, os espaços reabertos para discussão para uma ação de corte regional que viera a tona na política brasileira ainda na década de 1950 com o Grupo de Trabalho para o Desenvolvimento do Nordeste (GTDN), expõe concepções distintas novamente permeando o Estado brasileiro, convergindo com a necessidade de criação de alternativas as propostas tradicionais.

Uma proposta política que vem inserindo na pauta a criatividade e valorização da diversidade regional como vetor para transformação social na busca por maior equidade está vinculada ao Ministério da Cultura. A criação da Secretaria de Economia Criativa (SEC) torna-se outro marco na consolidação de propostas alternativas para o país. Cabe tecer algumas notas sobre a mesma pautada no Plano de Economia Criativa (PEC) confeccionado para balizar as ações da Secretaria.

Parte significativa da proposta presente no PEC dialoga com o marco teórico apresentado nesse artigo, sendo inclusive citados autores estruturalistas na busca por fundamentar os argumentos mencionados. Entre as afirmações do Plano, que corrobora com menções de diversos autores, se destaca a percepção da potencialidade brasileira no que tange uma proposta de valorização da criatividade a partir da diversidade cultural, fato objetivado com a PEC através da SEC, visto ao parco aproveitamento dessas possibilidades por razões anteriormente descritas. 
Concomitante a novas concepções de desenvolvimento que surge da apreciação da diversidade, o PEC da conta do fracasso dos modelos ortodoxos de 'desenvolvimento'. Estes não foram suficientes para diminuir o abismo social existente no Brasil e entre suas regiões.

Para realização desse esforço, é apresentado no PEC alguns limitantes para esse macro objetivo, entre os quais se salienta as poucas pesquisas no Brasil sobre a real potencialidade de desenvolvimento a partir da economia criativa. Essa falta exprimisse pelos poucos dados sistematizados sobre a temática no país, ponto situado e propostas ações para suprir essa deficiência, como financiamentos para pesquisas que gerem informações/métodos comparáveis e reproduzíveis em realidades distintas.

Em síntese, a percepção territorial do PEC é voltada para convergência de políticas, institucionalização de entes nos territórios para ação local, havendo determinadas práticas alinhadas com ações tradicionais, aproveitando oportunidades, como grandes eventos. Contudo, se salienta a nova percepção de criatividade para além da valorização cultural em si, abrangendo suas repercussões econômicas com inserção de circuitos marginais na economia.

A proposta do PEC, portanto dialoga com outras intervenções recentes do Estado brasileiro, contudo ainda é uma política recente, fato que afeta a análise dos resultados já alcançados. Porém, alguns desafios já podem ser percebidos nos primeiros anos da SEC na promoção da criatividade como vetor para desenvolvimento.

Entre as preocupações para a afirmação e intensificação dos esforços da SEC está a busca por executar a proposta de participação de dezesseis Ministérios como prevê o PEC. A aderência de mais pastas ministeriais, para além do Ministério da Cultura, insere transversalmente as reflexões sobre criatividade e desenvolvimento e propicia condições financeiras para materialização dos projetos.

Em contrapartida, o inverso também possui relevância, especialmente no que tange o financiamento. Linhas de oferta de crédito para materialização das ideias criativas devem ser disponibilizadas na escala local/regional. Entretanto, a origem dos recursos não deve estar pautada apenas nessas escalas devido a centralização dos recursos públicos na União, uma interação entre as três esferas de poder é primordial.

\subsection{CULTURA NA ESCALA LOCAL E O CONTRAPONTO NA ESCALA MACRO}

Mesmo que a concentração de recursos públicos no Brasil ocorra na escala nacional, diversos autores chamam atenção para a peculiaridade da cultura. Apesar desta também se expressar nacionalmente, é nas escalas locais e regionais que ela realmente acontece e marca no território suas peculiaridades que as diferenciam de outras. Assim, na escala local, administrativamente representada pelo município no Brasil, cabe realizar uma percepção entorno das repercussões territoriais dos investimentos públicos municipais em cultura.

Nesse sentido, concordamos com Leitão (2009) que traz a pertinência da aproximação das politicas culturais junto a escala local, no espaço administrativo do município. Dada a cultura como um processo social que ocorre no âmbito do meio vivido, a delimitação 
administrativa, no caso brasileiro, que mais se aproxima da peculiaridade de cada expressão cultural é o município.

A autora aborda a pertinência das discussões entorno de desenvolvimento vinculado a cultura ocorrerem baseados na valorização da diversidade a partir das suas expressões e concedendo poder de deliberação a eles mesmo, atribuindo assim, certo foco junto com as administrações locais. Sem dúvida, ao abordar a temática cultura, ações próximas a suas expressões são essenciais, visto que é no espaço vivido que se materializa - de forma simbólica ou não - sua produção, tornando pertinente levar a mais próximo possível dessa escala determinados aspectos deliberativos.

Assim, atribuída os protagonismos necessários a escala local, esta nos parece limitada se abordada em sua exclusividade. As arenas de decisão não se limitam ao espaço local. $\mathrm{O}$ território é fruto de uma construção endógena e exógena, no caso brasileiro em especial, a administração pública tríade, articulada com uma representação social tão particular como a cultura, acaba exigindo uma analise multiescalar.

Contudo, Ribeiro e Milano (2008, p.12) chamam a atenção para algumas reflexões contemporâneas que abordam, na concepção dos autores, de forma equivocada ações de cunho território, não como ambiente de disputa, de contradições, mas simplificadamente como um espaço inerte, dado:

Infelizmente, em parte ponderável da literatura contemporânea, o território, que deveria ser visto como ambiente politizado, em conflito e em construção, é posto como reificado, ente mercadejado e passivo, mero receptáculo, onde se inscrevem os deslocamentos/ movimentos. [...] A abordagem do território deve se afastar dos tratamentos que pensaram estruturas sem decisões de sujeitos ou atores sem contexto estrutural. Territórios são construções (sociais, discursivas e materiais), portanto sua análise deve se basear na interação entre decisões e estruturas, nas articulações entre microprocessos, microiniciativas versus macro decisões nas várias escalas em que se estruturam e se enfrentam os interesses em disputa (RIBEIRO; MILANO, 2008, p.12).

Nessa concepção, os autores propõem uma visão mais ampla e dinâmica de ações que venham a se materializar em determinado território, abrangendo não apenas a escala micro, mas também as influências exógenas, sejam nacionais ou globais que se somam as forças horizontais, as representatividades sociais e culturais que se fazem a partir 'de baixo', do próprio território.

Corroborando com essa perspectiva Brandão (2010) afirma, tratando de escalas, um território não estático, composto por relações que o extrapolam e fruto de divergências e convergências de poder. $\mathrm{O}$ autor questiona "quem são os agentes envolvidos nas decisões que repercutem no território?”, “onde estão?”, “será que apenas em uma escala?”. De acordo com Pochmann (2010), tais perguntas vêm tendo respostas distintas em cada momento histórico do Brasil, cabendo considerá-lo.

É central na abordagem realizada pelo autor a relevância das questões do poder na abordagem da dimensão espacial do processo de decisões públicas, as hierarquias e hegemonias. Não obstante, cabe perceber as arenas decisórias, pois, apesar de ações serem vividas no local, a ação de intervenção, assim como a possibilidade financeira dessa, estão distantes dessa escala. A proposta central de Brandão (2010) é articular processos que 
parecem isolados em uma escala, com as demais, as relações de troca existentes, percebendo o papel do Estado, das reorganizações produtivas, enfim.

Brandão (2010) não desconsidera o local como elemento relevante para compreensão dos processos de construção do desenvolvimento a partir de políticas públicas, afirmando ser indispensável indagar as recorrências, persistências, rupturas e transformações ao longo de um processo histórico de formação do território, evidenciando as razões do atualmente forjado e como ocorreu o processo de evolução.

Contudo apenas a escala local é insuficiente para abranger a complexa relação de decisões que inferem sobre um território. Avançar sobre a percepção dos agentes decisórios em múltiplas escalas se faz necessário. Perceber hierarquias, fatos endógenos e exógenos determinantes, condicionantes ou coadjuvantes dos processos que definem o território, as relações econômicas, sociais, culturais, etc.

Somado ao fato da cultura possuir um caráter interescalar e as decisões políticas terem interface em diferentes instancias administrativas, o Estado brasileiro em sua escala nacional é responsável por mais da metade dos recursos públicos, sendo imprescindível reconhece-lo como elemento fundamental nas análises espaciais e materialização de projetos em distintos segmentos.

\section{A PESQUiSA "A ALOCAÇÃo DE RECURSOS PÚbliCOS E A POSSIBILIDADE DE CONFIGURAÇÃO DE UM ARRANJO PRODUTIVO DA CULTURA REGIONAL: A 'ROTA MISSÕES' NO RIO GRANDE DO SUL": MÉTODO E O DESLOCAMENTO DE RECURSOS PÚBLICOS NA CULTURA}

Baseado na trajetória política e econômica do Brasil, assim como das reflexões teóricas sobre as distintas abordagens escalares necessárias ao analisar a cultura, o presente artigo, fração da pesquisa "A alocação de recursos públicos e a possibilidade de configuração de um arranjo produtivo da cultura regional: a "Rota Missões" no Rio Grande do Sul", traz a discussão sobre as repercussões territoriais do investimento público em cultura, realizado pelas prefeituras municipais da Região "Rota Missões" do Rio Grande do Sul.

A pesquisa supracitada, que teve financiamento do Ministério da Cultura e foi realizada durante o ano de 2014, teve por objetivo verificar, por meio das ações realizadas pelas prefeituras municipais na região das Missões, o papel das políticas públicas na alavancagem de um arranjo produtivo da/na cultura regional. Não entraremos no presente artigo em discussões que remetem a política púbica. Limitamo-nos a apontar a intersecção existente entre as distintas escalas e as políticas praticadas, assim como as tendências recentes na política nacional.

Entretanto, trazemos a discussão entorno das repercussões territoriais que foram debatidas e percebidas na pesquisa supracitada. Para compreender tais informações, cabe descrever o processo metodológico utilizado, para assim apresentar os dados e as discussões pertinentes. 
A proposta metodológica pode ser dividida em quatro momentos. O primeiro foi a captação dos dados brutos que foram a base para as etapas seguintes. Buscou-se informações de alocação de recursos realizados pelas prefeituras junto ao portal do Tribunal de Contas do Estado do Rio Grande do Sul (TCE/RS) oriundas do Sistema de Informações para Auditoria e Prestação de Contas (SIAPC). O portal disponibiliza, como forma de controle social, as despesas e receitas das prefeituras por ano orçamentário e divididas por pastas administrativas existentes no executivo local.

O sistema possibilita verificar o órgão (as unidades, as funções, as subfunções, projetos, atividades e recursos vinculados a outras instâncias de governo), o credor (com o número do Cadastro de Pessoa física (CPF), ou jurídica (CNPJ), a rubrica (de acordo com o que foi estipulado no orçamento do município) e a função (como saúde, educação, transporte, cultura, etc.).

O ordenamento e a organização dessas informações possibilita a criação de variáveis numéricas e nominais que puderam receber tratamento estatístico oportuno para a resolução dos objetivos estabelecidos na pesquisa. Para os fins metodológicos é preciso ater-se em alguns pontos: (1)A alocação de recursos públicos está descrita no empenho em moeda corrente, tendo por premissa o uso daqueles empenhos que efetivamente foram pagos pela prefeitura; (2)A atividade principal e o município estão associados ao Cadastro Nacional de Pessoa Jurídica, portanto obedeceu este registro na localização territorial da empresa e na definição da Classificação Nacional de Atividades Econômicas-Fiscal (CNAE-Fiscal); e (3)Para analisar as despesas públicas na cultura nos municípios foram ordenados os empenhos referentes ao tópico - Cultura, código - 13 do Tribunal de Contas do Estado.

A segunda etapa, de caráter sistematizador dos dados anteriormente levantados, teve por finalidade organizar os dados brutos buscados com a pretensão de alinhar a possibilidade de identificação de cadeias produtivas da cultura. Baseou-se a proposta em duas metodologias já utilizadas, uma pela Federação das Indústrias do Estado do Rio de Janeiro (FIRJAN) e outra pela Fundação de Economia e Estatística do Rio Grande do Sul (FEE), ambas fazendo uso da Classificação Nacional de Atividades Econômicas (CNAE).

As categorias utilizadas por ambos os estudos são: atividades nucleares; atividades relacionadas; e atividades de apoio. Uma importante diferença entre a metodologia utilizada por ambas instituições e a pesquisa que se realizou, é o nível de detalhamento proposto. Enquanto ambas usam uma categorização a partir do CNAE 2.0 para classes, se utiliza uma estrutura hierárquica de classe com cinco dígitos no código CNAE. Já a pesquisa realizada na região Rota Missões do RS, com a possibilidade trazida pelo cadastro do CNPJ junto a receita federal, foi buscado as subclasses 2.1, com detalhamento de sete dígito das atividades realizada pelas empresas.

Ao abordar com maior detalhamento as atividades realizadas pelas empresas contratadas pelas prefeituras municipais, se percebeu que alguns códigos CNAE que não estavam contidos nas categorizações da Firjan e FEE, mas eram perceptíveis nos empenhos das prefeituras. Assim, foram criadas duas novas categorias de atividades CNAE dentro da proposta de estudo: atividades de apoio II; e transferências governamentais.

A terceira etapa, também de caráter sistematizador, aproximou as atividades econômicas levantadas na primeira etapa aqui descritas com categorias culturais. Estas 
categorias foram retiradas das propostas da Secretaria de Economia Criativa, ligada ao Ministério da Cultura, que propôs uma categorização das atividades criativas a fim de criar a possibilidade de pesquisas e a aplicação de recursos no setor serem minimamente comparáveis e com uma definição a partir das atividades realizadas.

As categorias culturais trazidas são: campo do patrimônio; campo das expressões culturais; campo das artes e espetáculos; campo áudio visual e do livro; e campo das criações culturais e funcionais. Cada categoria possui subcategorias, como por exemplo, no campo do patrimônio o subcampo de museus, patrimônio imaterial, e assim por diante.

A partir dessa proposta o presente estudo realizou uma aproximação entre a classificação das atividades econômicas, as dimensões da cadeia produtiva da cultura (nuclear, relacionada e apoio) e as categorias culturais apontadas pelo Ministério da Cultura. Em outros termos, como está se trabalhando com subclasses, os códigos CNAE apresentam um maior detalhamento das atividades que permitem uma representação, uma proxy, do código em relação à cadeia produtiva e à categoria cultural. Desta forma foi viável, em grande medida, categorizar os códigos em nucleares no campo do patrimônio, relacionadas no campo do patrimônio e assim sucessivamente nos demais setores criativos e culturais. Foi possível a realização dessa sistematização apenas com as atividades nucleares e relacionadas, visto a distancia entre a atividade realizada na categoria de apoio com a cultura, contudo, foi evidenciada sua importância para o estudo.

Por fim, a quarta e última etapa teve como finalidade buscar identificar cadeias produtivas entorno dos segmentos culturais, assim como de uma cidade polo na Região Rota Missões. Esta etapa que está sendo evidenciada no presente artigo. Utilizando-se dos dados de CNPJ apresentados pelo Tribunal de Contas do Estado, e buscando a localização do empreendimento via Receita Federal, se pode realizar uma análise territorial dos deslocamentos dos investimentos em cultura na Região Rota Missões.

As análises das matrizes para identificação de cadeias produtivas realizadas se utilizou de técnicas de agrupamentos em duas frentes: as setoriais e territoriais. Determinados cortes suplementares são necessários a medida que em maior ou menor peso, os setores não são estanques, pois dialogam com outros.

Assim, fazendo uso da categorização utilizada nessa pesquisa, somou-se todos os empenhos pagos pelas prefeituras municipais em atividades nucleares e relacionais em cada setor de atividade cultural - patrimônio; expressões culturais; artes de espetáculo; audiovisual e do livro; e criações funcionais - para identificação de qual(is) se sobressae(m) nas trocas entre administrações públicas e CNPJ de prestação de serviços e/ou aluguel/venda de bens. A cadeia produtiva é visualizada pela concentração de recursos em cada categorização. Exemplo: o campo das artes de espetáculo apresenta um gasto $\mathrm{X}$ em atividades nucleares $\mathrm{e}$ um gasto $\mathrm{Y}$ em atividades relacionadas. Desta forma é possível identificar se a prefeitura, como agente principal, fomenta ela propriamente uma cadeia produtiva; e, por outro lado, se a convergência dos CNPJ aponta para a configuração de uma cadeia produtiva em outro território, de acordo com uma análise cultural ampla ou restrita a determinado setor cultural. Neste último se estabelece uma compreensão e articulação com a análise territorial, oportuna devido a possibilidade de identificação de uma delimitação geográfica - mesmo que não estanque - das cadeias setoriais da cultura, ou seja, somando a discussão de cidade polo, se pode perceber a existência ou não de eixos sub-regionais de especialização de oferta de bens 
em determinado segmento, caracterizando uma cadeia produtiva com interface setorial e territorial.

Nesse contexto, identificar a cidade-polo mobilizada pelos recursos públicos de outras cidades é metodologicamente percebido, pela compreensão de dados contínuos e dados discretos, assim apresentados: (1) Valor de recursos financeiros (R\$) destinados à cidade nas atividades nucleares, relacionadas e de apoio, realizado pela prefeitura da cidade. (2) Valor de recursos financeiros $(\mathrm{R} \$)$ destinados à cidade nas atividades nucleares, relacionadas e de apoio, realizado pelas demais prefeituras; (3) Cidade que concentrou uma quantidade significativa de demanda por bens e serviços (nucleares, relacionados e de apoio) de outras cidades (prefeituras) - número de cidades.

A diferença entre as premissas procura traduzir o pensamento de que não é possível reconhecer uma cidade-polo somente pela concentração de recursos financeiros. Sabe-se que a cultura possui um alto valor agregado e que isso poderia distorcer a leitura. Exemplo: um show musical de um cantor famoso pode representar uma dezena de show de cantores menos reconhecidos (pela crítica, público, etc.).

Assim, perceber os recursos financeiros no eixo central da cadeia produtiva (nuclear, relacionada e de apoio) pode demonstrar de forma mais satisfatória que a cidade possui elos mais densos e reconhecidos dentro do sistema produtivo criativo e cultural. A segunda premissa procura perceber a lógica da distância que o agente consumidor (prefeitura que fomenta a cultura) está disposto a —viajar para adquirir os bens e serviços. Assim, uma cidade-polo terá uma quantidade maior de agentes consumidores de outros lugares adquirindo tais atividades.

\subsection{REPERCUSSÕES TERRITORIAIS DOS INVESTIMENTOS PÚBLICOS MUNICIPAIS EM CULTURA NA REGIÃO DAS MISSÕES DO RIO GRANDE DO SUL, BRASIL}

Para tabulação e mapeamento dos dados referentes ao destino dos pagamentos realizados pelas prefeituras municipais foi utilizada a configuração espacial do gasto: (i) gastos realizados no próprio município ou em municípios da região Rota Missões; e (ii) gastos em municípios fora da região Rota Missões. E sobre a atividade do bem ou serviço contratado: (i) nuclear (dentro de cada categoria cultural: expressões culturais; artes de espetáculo; audiovisual e do livro; etc.); (ii) relacionadas (também dentro de cada categoria cultural); e (iii) apoio. Assim, os mapeamentos realizados na sequência procuram elucidar, com mais ênfase, o deslocamento dos gastos realizados na região das Missões. Inicia-se com as atividades nucleares: 
Figura 1 - Mapa do deslocamento territorial das atividades nucleares no próprio município e na região —Rota Missões

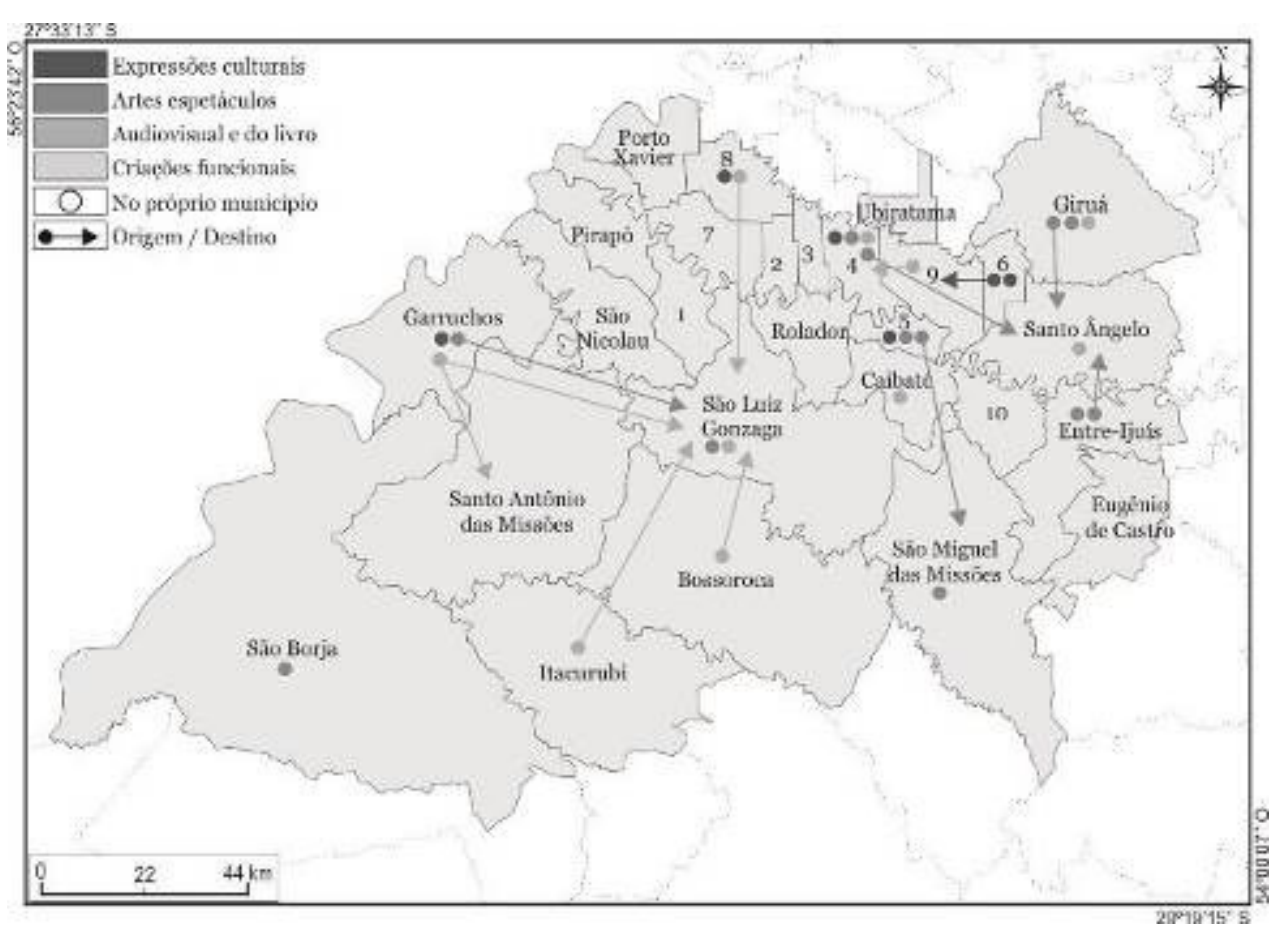

Fonte: Elaborado pelos autores, baseado em TCE (2014) e Receita Federal (2014). 1. Dezesseis de Novembro; 2. São Pedro do Butiá; 3. Salvador das Missões; 4. Cerro Largo; 5. Mato Queimado; 6. Sete de Setembro; 7. São Paulo das Missões; 8. Roque Gonzales; 9. Guarani das Missões; 10. Vitória das Missões.

Os pontos caracterizam haver um gasto público junto a um CNPJ do município (não está representado o número de empenhos e os valores). As setas se referem aos gastos efetivados pelas prefeituras junto a CNPJ de município da região Rota Missões. Pelo esquema é possível perceber que os gastos em atividades nucleares tiveram um tímido deslocamento regional. Em termos de categorias culturais o campo do audiovisual e do livro apontou algum deslocamento para o município de São Luiz Gonzaga. Assim como Santo Ângelo demonstrou alguma atuação no campo das artes de espetáculo. Em síntese, as atividades nucleares foram de parco deslocamento na região, podendo estar concentradas no próprio município ou além da região.

A figura a seguir destaca o deslocamento territorial das atividades relacionadas. Notase, em paralelo às nucleares, uma maior mobilidade dos empenhos, entretanto não de forma homogênea entre as categorizações. Por exemplo, as atividades de patrimônio ficaram restritas a três municípios: São Borja, São Luiz Gonzaga e Caibaté. Ao mesmo passo, as atividades de expressões culturais também não obtiveram grande mobilidade dentro da região Rota das Missões. Em contrapartida, as atividades relacionadas de artes de espetáculo apresentaram interessante deslocamento, especialmente com gastos realizados junto a CNPJ de Santo Ângelo, com sete municípios da região buscando bens e/ou serviços no município. 
Figura 2 - Mapa do deslocamento territorial das atividades relacionadas no próprio município e na região -Rota Missões

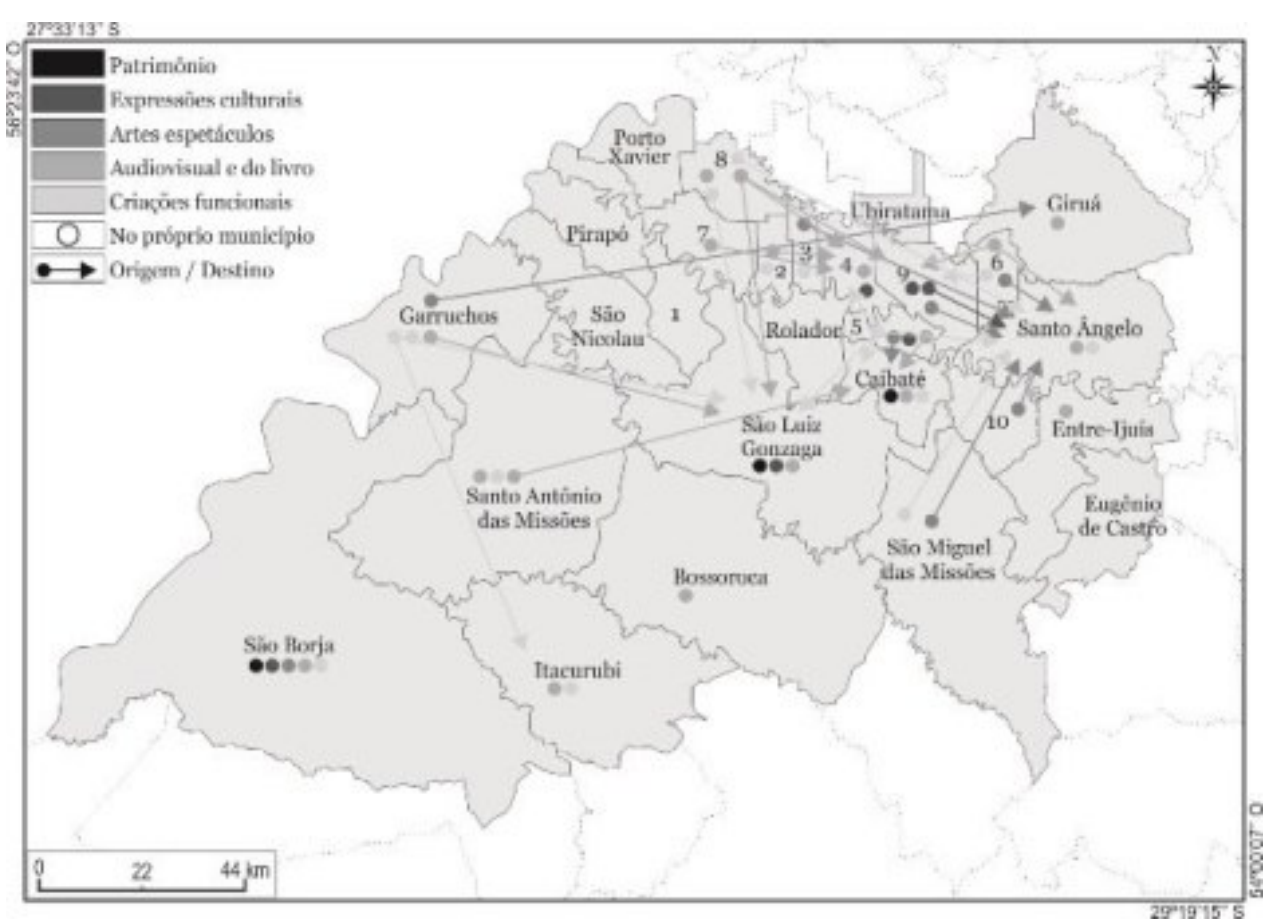

Fonte: Elaborado pelos autores, baseado em TCE (2014) e Receita Federal (2014). 1. Dezesseis de Novembro; 2. São Pedro do Butiá; 3. Salvador das Missões; 4. Cerro Largo; 5. Mato Queimado; 6. Sete de Setembro; 7. São Paulo das Missões; 8. Roque Gonzales; 9. Guarani das Missões; 10. Vitória das Missões.

De modo geral, as atividades relacionadas mostram o município de Santo Ângelo como o principal destino de gastos realizados pelas prefeituras na região, sendo buscado por nove administrações públicas. Outro destaque similar ao ocorrido nas atividades nucleares é São Borja não empenhar bens e serviços de outros municípios da região e não ser procurado por nenhum. Há aqui um indício de pouco diálogo regional entre São Borja e o restante da região.

Já as atividades de apoio acabam por destacar que a pouca especialização dessas atividades viabiliza a realização do gasto público dentro do próprio município. Como é possível perceber no mapa abaixo, somente São Luiz Gonzaga e Santo Ângelo tiveram deslocamentos regionais de outras prefeituras para esse tipo de atividade. 
Figura 3 - Mapa do deslocamento territorial das atividades de Apoio no próprio município e na região - Rota Missões

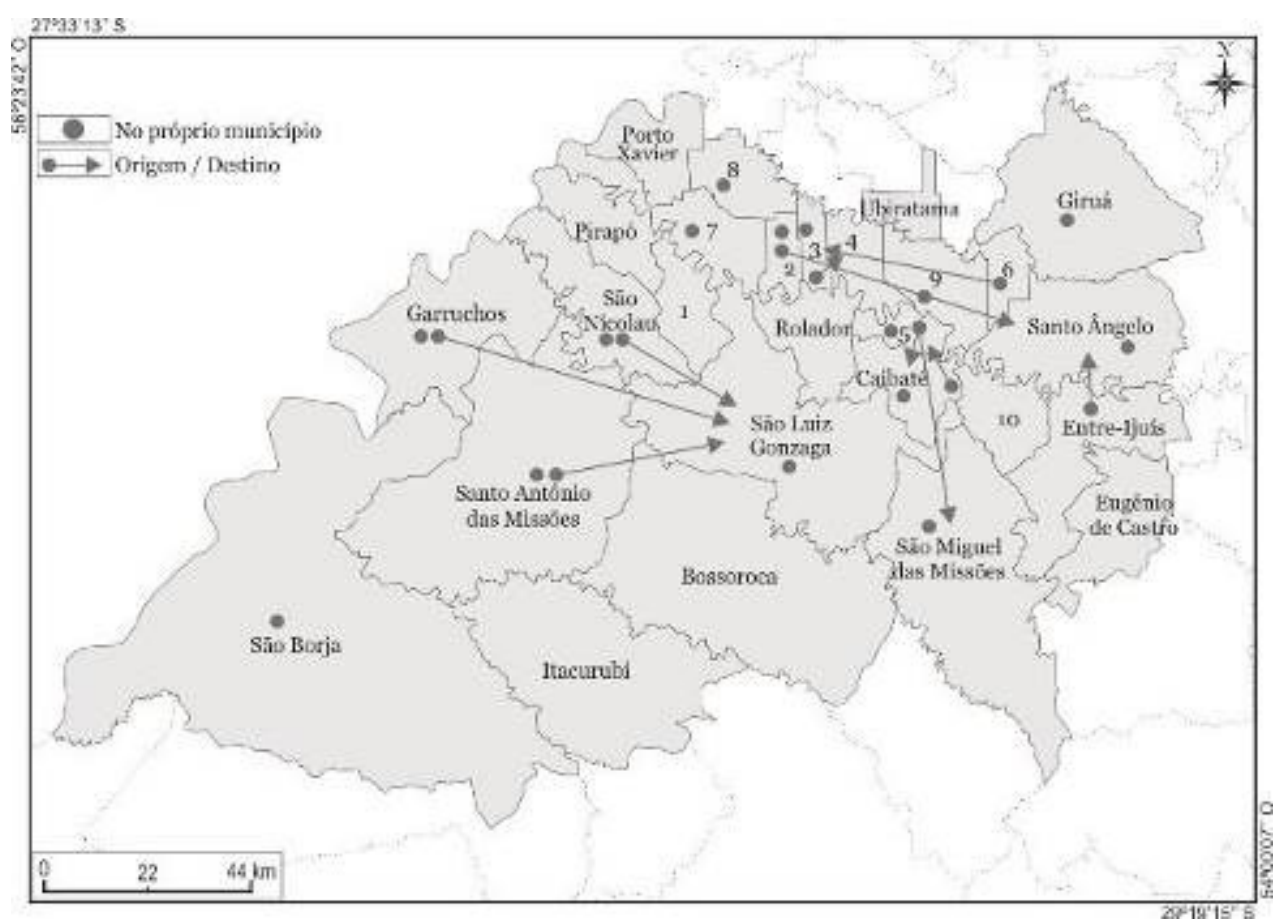

Fonte: Elaborado pelos autores, baseado em TCE (2014) e Receita Federal (2014). 1. Dezesseis de Novembro; 2. São Pedro do Butiá; 3. Salvador das Missões; 4. Cerro Largo; 5. Mato Queimado; 6. Sete de Setembro; 7. São Paulo das Missões; 8. Roque Gonzales; 9. Guarani das Missões; 10. Vitória das Missões.

O segundo ponto de mapeamento dos gastos públicos em cultura foi posto a partir do deslocamento transregional, ou seja, a partir dos gastos que foram estabelecidos com CNPJ de empresas fora da região das Missões (Rota Missões). Assim, o mapa abaixo procura apresentar o deslocamento por meio de símbolos que representam os municípios sedes das empresas. 
Figura 4 - Empenhos realizados em atividades nucleares fora da região — Rota Missões

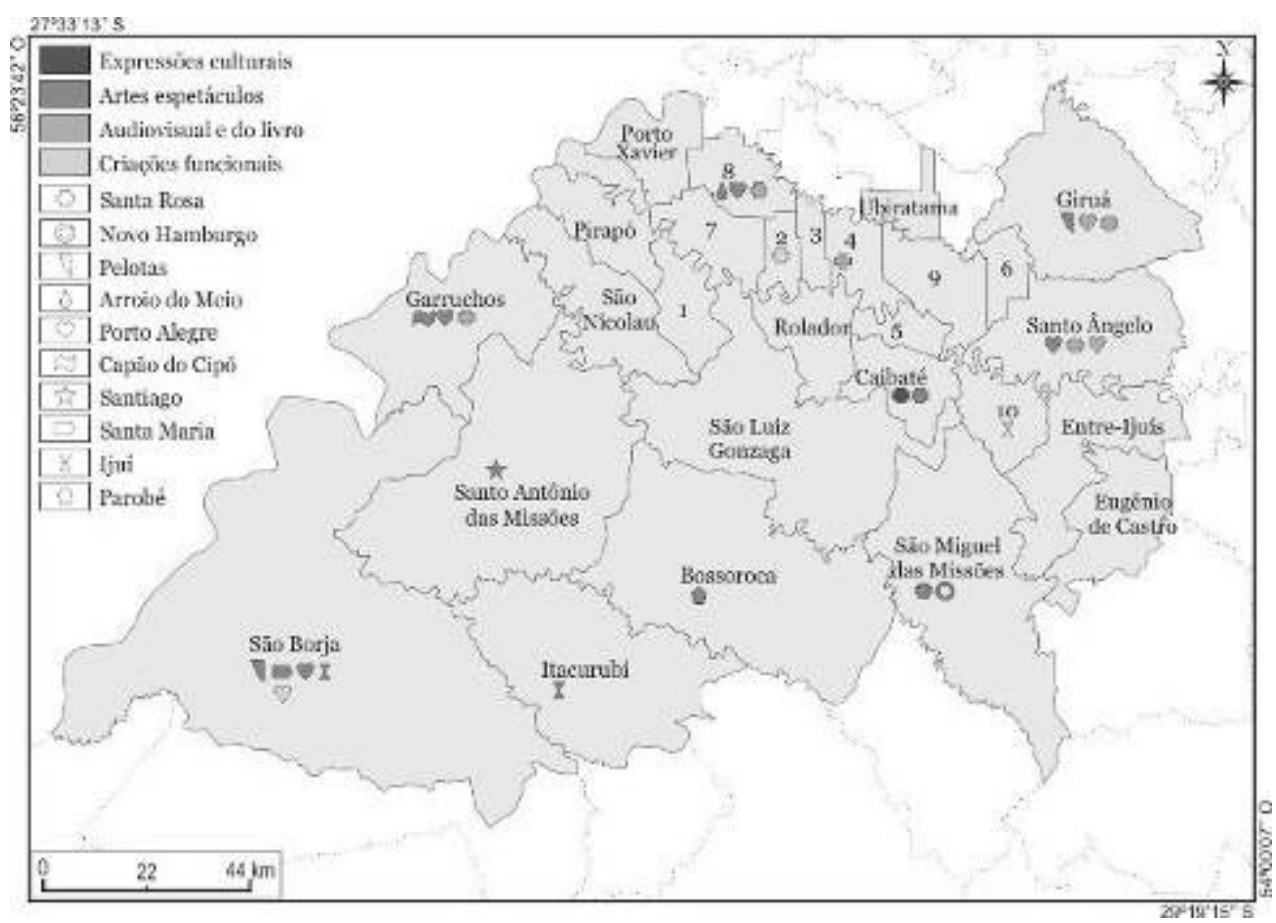

Fonte: Elaborado pelos autores, baseado em TCE (2014) e Receita Federal (2014). 1. Dezesseis de Novembro; 2. São Pedro do Butiá; 3. Salvador das Missões; 4. Cerro Largo; 5. Mato Queimado; 6. Sete de Setembro; 7. São Paulo das Missões; 8. Roque Gonzales; 9. Guarani das Missões; 10. Vitória das Missões.

O esquema demonstra que as prefeituras buscaram com maior intensidade CNPJ externos à região em atividades de —artes de espetáculo, com dez prefeituras procurando bens e serviços fora da região. Informação que já não é estranha por conta dos valores gastos pelas prefeituras nessa categoria cultural, conforme visto anteriormente. Também é interessante notar que São Borja, com pouco diálogo regional, procura bens e serviços culturais em territórios/cidades distantes da região da Rota Missões. Já no que concerne às atividades nucleares e o deslocamento territorial se percebe uma predominância da busca por dois municípios: Santa Rosa e Ijuí.

Por seu turno, os deslocamentos em atividades relacionadas para fora da região, em comparação às atividades nucleares, podem ser considerados tímidos. Neste caso é importante recordar que os deslocamentos dentro da região nesse item foram intensos, conforme apontado anteriormente. Eis que se pode inferir que havendo uma dinâmica intrarregional de atividades relacionadas com maior expressão, os deslocamentos para fora dos limites regionais tenderam ser menores. Veja o mapa a seguir: 
Figura 5 - Empenhos realizados em atividades relacionadas fora da região - Rota Missões

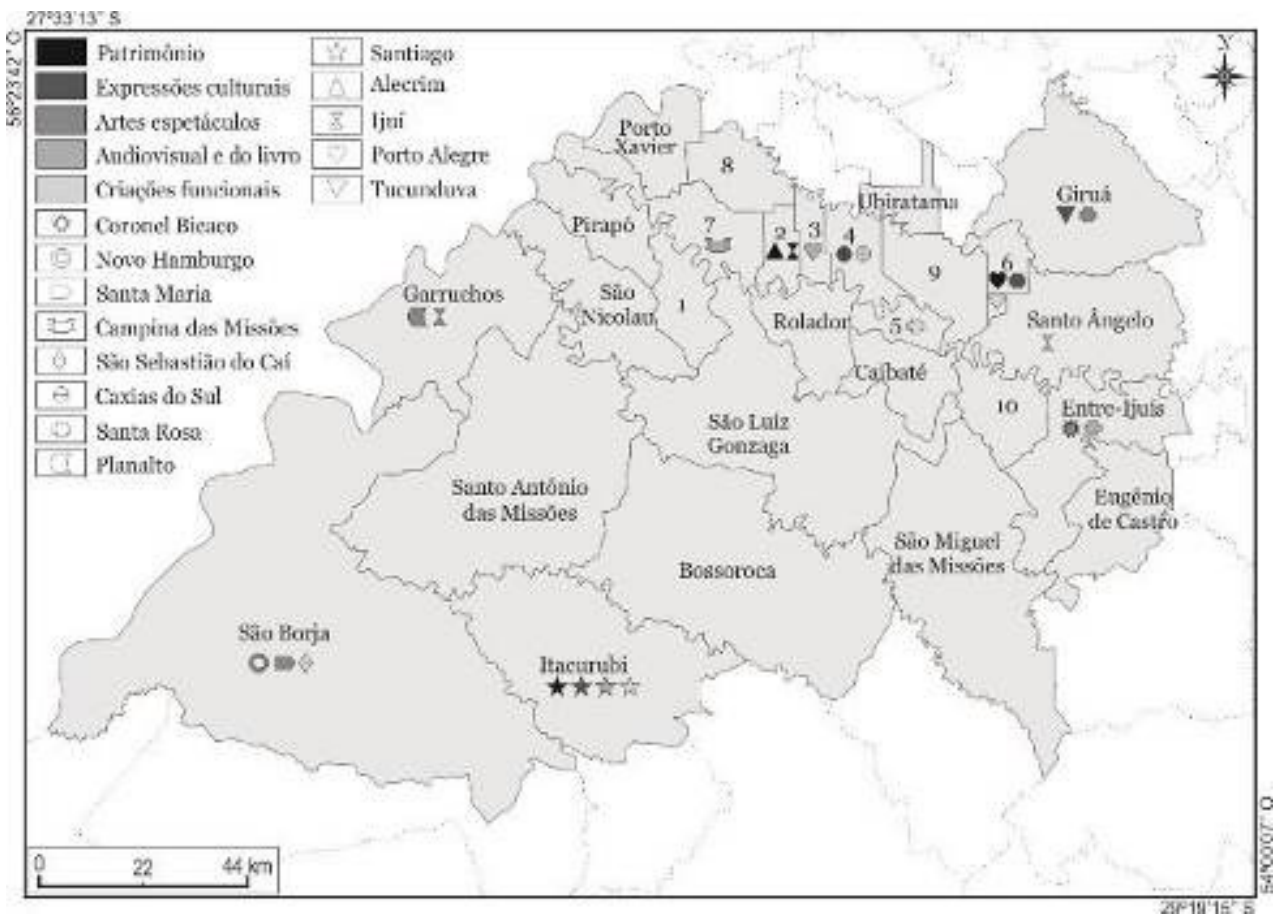

Fonte: Elaborado pelos autores, baseado em TCE (2014) e Receita Federal (2014). 1. Dezesseis de Novembro; 2. São Pedro do Butiá; 3. Salvador das Missões; 4. Cerro Largo; 5. Mato Queimado; 6. Sete de Setembro; 7. São Paulo das Missões; 8. Roque Gonzales; 9. Guarani das Missões; 10. Vitória das Missões.

Por fim, entre os gastos realizados pelos municípios em atividades de apoio fora da região, novamente se destaca Santa Rosa como principal destino. Ao todo cinco prefeituras buscaram o município. No entanto, se seguiu a tendência de dinâmica territorial dos gastos em atividades relacionadas com os de apoio: permaneceram na região e/ou nos próprios municípios. 
Figura 6 - Empenhos realizados em apoio fora da região —Rota Missões

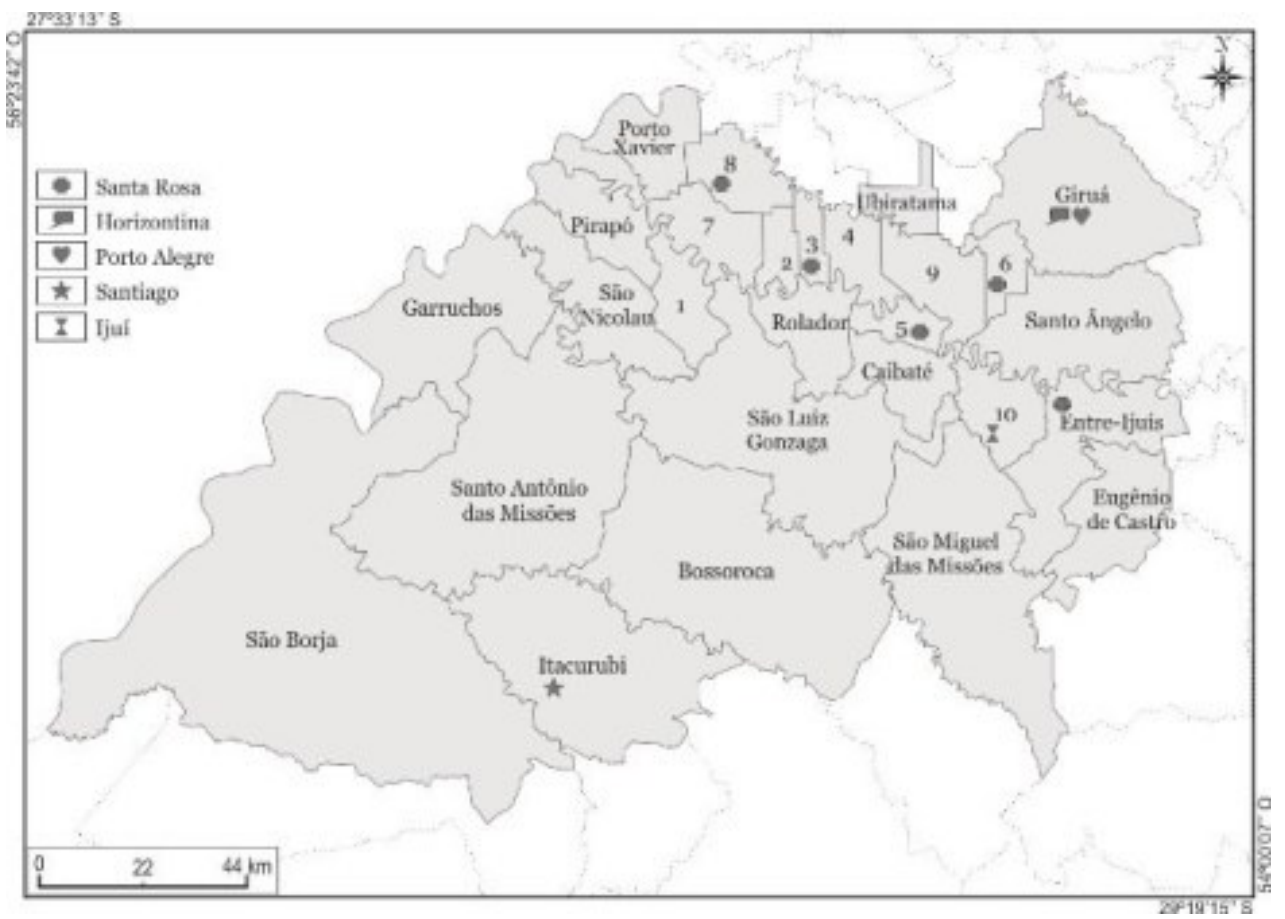

Fonte: Elaborado pelos autores, baseado em TCE (2014) e Receita Federal (2014). 1. Dezesseis de Novembro; 2. São Pedro do Butiá; 3. Salvador das Missões; 4. Cerro Largo; 5. Mato Queimado; 6. Sete de Setembro; 7. São Paulo das Missões; 8. Roque Gonzales; 9. Guarani das Missões; 10. Vitória das Missões.

Por fim, entre os gastos realizados pelos municípios em atividades de apoio fora da região, novamente se destaca Santa Rosa como principal destino. Ao todo cinco prefeituras buscaram o município. No entanto, se seguiu a tendência de dinâmica territorial dos gastos em atividades relacionadas com os de apoio: permaneceram na região e/ou nos próprios municípios.

Nessa conjuntura, a configuração de uma cidade-polo em bens e serviços culturais foi pensada considerando três indicadores (como referidos anteriormente): (1) o valor de recursos financeiros $(\mathrm{R} \$)$ destinados à cidade nas atividades nucleares, relacionadas e de apoio, realizado pela prefeitura dessa mesma cidade; (2) o valor de recursos financeiros (R\$) destinados à cidade nas atividades nucleares, relacionadas e de apoio, realizado pelas demais prefeituras; e (3) a cidade que concentrou uma quantidade significativa de demanda por bens e serviços (nucleares, relacionados e de apoio) de outras cidades (prefeituras) - número de cidades.

Esses três indicadores, mesmo não estabelecendo um peso para cada um ao se fazer a análise, foram reunidos para uma reflexão e apontamento de qual município seria indicado como uma cidade-polo de bens e serviços culturais. Vale dizer que esta proposta foi um exercício aproximativo a partir dos dados disponíveis com a pesquisa.

Eis que por essa ordem foi possível ler qual cidade tem propensão de ser reconhecida como cidade-polo. O quadro a seguir apresenta o percentual de recursos concentrado nos municípios da região através do gasto realizado pela sua e pelas demais prefeituras, assim 
como o número de município/prefeituras que procuraram bens e serviços em cada cidade nas atividades nucleares, relacionadas e de apoio.

Tabala 1 - Cidade-polo na região das Missões (percentual de recursos na cadeia produtiva da cultura por cidade e número de cidades demandantes) (seleção) (2013).

\begin{tabular}{|c|c|c|c|}
\hline Cidade região das Missões & $\begin{array}{l}\text { (1) \% recursos da própria } \\
\text { prefeitura }\end{array}$ & $\begin{array}{l}\text { (2) \% recursos de outras } \\
\text { prefeituras }\end{array}$ & $\begin{array}{l}\text { (3) prefeituras } \\
\text { demandantes } \\
\end{array}$ \\
\hline Caibaté & 1,56 & 1,29 & 2 \\
\hline Cerro Largo & 1,92 & 0,37 & 5 \\
\hline Giruá & 1,55 & 0,28 & 1 \\
\hline Mato Queimado & 2,64 & 0,08 & 1 \\
\hline Santo Ângelo & 1,07 & 13,56 & 11 \\
\hline São Borja & 10,26 & & \\
\hline São Luiz Gonzaga & 10,46 & 1,85 & 7 \\
\hline São Miguel das Missões & 4,37 & 1,22 & 2 \\
\hline
\end{tabular}

Fonte: próprios autores (2014).

Nota-se que a leitura dos três indicadores destaca o significativo percentual de recursos concentrados dentro da própria cidade em São Borja e São Luiz Gonzaga. A primeira demonstra não ter nenhum diálogo produtivo em bens e serviços culturais com os demais municípios da região, já que não teve nenhum percentual de recursos de outras prefeituras (e consequentemente nenhuma prefeitura demandante). Por seu turno, São Luiz Gonzaga apesar de ter tido sete prefeituras demandantes de bens e serviços, não apresentou um valor significativo nos recursos dispendidos de outras prefeituras $(1,85 \%)$.

Santo Ângelo é o caso mais saliente na percepção de uma cidade-polo regional de bens e serviços na economia da cultura. A pífia concentração de recursos na cadeia produtiva da cultura estabelecida pela própria prefeitura da cidade é contraposta pelo percentual mais alto de recursos destinados de outras prefeituras da região $(13,56 \%)$. Para corroborar com essa leitura, recordando o valor agregado presente na cadeia da cultura, a presença de 11 prefeituras da região demandantes de bens e serviços no setor dão indícios do reconhecimento de Santo Ângelo como cidade-polo regional de bens e serviços culturais. No entanto, não necessariamente as prefeituras procuraram bens e serviços em cidades da região. Como visto no deslocamento territorial dos gastos, as despesas em cultura transcenderam os limites das cidades, da região e, até mesmo, do Rio Grande do Sul. Assim, o quadro abaixo apresenta as demais cidades, fora da região, que também concentraram recursos da região. 
Tabela 2 - Demais cidades com destinação de recursos da região das Missões (percentual de recursos na cadeia produtiva da cultura por cidade e número de cidades demandantes) (seleção) (2013)

\begin{tabular}{l|c|c}
\hline \multicolumn{1}{c|}{ Demais cidades } & $\begin{array}{c}\text { (2) } \% \text { recursos de outras } \\
\text { prefeituras }\end{array}$ & (3) prefeituras demandantes \\
\hline Ijuí & 9,35 & 6 \\
\hline Novo Hamburgo & 0,64 & 2 \\
\hline Parobé & 0,96 & 2 \\
\hline Pelotas & 1,69 & 1 \\
\hline Planalto & 0,89 & 8 \\
\hline Porto Alegre & 2,54 & 1 \\
\hline Santa Maria & 17,29 & 12 \\
\hline Santa Rosa & 4,97 & 2 \\
\hline Santiago & 0,53 & 1 \\
\hline Tucunduva & 3,71 & \\
\hline Fonte: Os aut & & \\
\hline
\end{tabular}

Fonte: Os autores (2014).

Santa Maria apresentou um percentual significativo dos recursos $(17,29 \%)$, mas apenas um município procurou os bens e serviços da cidade, ou seja, isso se deve por conta de alguma atividade adquirida ou contratada com alto valor agregado. Santa Rosa foi mais tímida na concentração dos recursos $(4,97 \%)$, mas em compensação foi "procurada" por 12 municípios da região das Missões. Já a cidade de Ijuí teve um percentual de 9,35 e a presença de 06 prefeituras demandantes. Por esses dados não se pode inferir que essas cidades são polos culturais de bens e serviços, mas por se tratar de um universo de apenas vinte e sete municípios da região das Missões, os indicadores dão indícios de que tais cidades concentram bens e serviços culturais.

De todo modo, os dois quadros acabam por apontar que a atuação de Santo Ângelo como polo regional de bens e serviços culturais deve ser reconhecida potencialmente, ou seja, entre Santa Maria e Santo Ângelo a primeira supera em termos de percentual de recursos, mas é posta em suspensão e resulta no destaque de Santo Ângelo em número de prefeituras demandantes. Já entre Santa Rosa e Santo Ângelo a primeira foi procurada por doze prefeituras em contraponto a Santo Ângelo com onze; vale dizer, diferença pouco significativa. Em termos de recursos, Santo Ângelo com 13,56\% desponta Santa Rosa com $4,97 \%$.

Não se pode negar, assim, que a presença de bens e serviços da cadeia produtiva da cultura (nucleares, relacionadas e de apoio), mesmo com o parco recurso total despendido pelas prefeituras, aponta para uma força potencial de Santo Ângelo como uma cidade-polo regional no âmbito da cultura. Reconhece-se, no entanto, a necessidade de uma projeção no tempo (com a mensuração de outros anos do estudo) e no espaço (com o ganho de escala e a leitura de todo o Rio Grande do Sul), pois pode ser que essa expressividade se disperse em valores e prefeituras demandantes. 


\section{CONCLUSÕES}

A reflexão sobre a alocação de recursos públicos no campo cultural é precedido por uma discussão mais ampla que possibilita aproximar a contextualização histórica com a ação pública. Sem dúvida um dos pontos de maior influência na aplicação dos recursos públicos está ligado aos agentes diretamente ligados, suas concepções sobre a ação governamental e afiliações ideológicas. Contudo, como refletimos a partir da história brasileira, o contexto político e econômico da escala nacional e internacional possui importante peso.

Não obstante, a abertura de campo político para novas possibilidades de articulação governamental para aplicação de recursos púbicos caminha nesse linear. Assistimos no Brasil em anos recentes a ampliação dos procedimentos de construção de políticas públicas, havendo maior espaço para ações intersetoriais, interescalares e pondo em pauta temas e agentes até então marginalizados da tutela do Estado.

Um setor que ganhou maior atenção por parte das ações do governo federal nos últimos anos foi a cultura. Guarnecido por planos e ações que propõe compilação de um maior número de pastas, o setor cultural vem ocupando assento nas pautas de desenvolvimento, quando até então era simplificada a intervenções pontuais e compensatórias. Para além da questão macro, de suma importância na articulação geral e financiamento, vem havendo esforço em levar a pauta da cultura para escalas próximas de onde ela é produzida e representada, o local. A deliberação e processo de construção necessita ocorrer próximo e abrangendo agentes que 'fazem' a cultura, por esse aspecto, o município assume relevância no processo de promoção pública do setor.

Nessa ordem, a pesquisa "A alocação de recursos públicos e a possibilidade de configuração de um arranjo produtivo da cultura regional: a "Rota Missões" no Rio Grande do Sul" buscou perceber o Estado, a partir da aplicação de recursos pelo município, fomentava o setor cultural no município. Para além do macro objetivo, foi buscado perceber as repercussões territoriais da intervenção estatal, sobre tudo fazendo uso dos dados de fluxo de recursos entre as cidades da região e para fora dela, com informações do Tribunal de Contas do Estado do Rio Grande do Sul e da Receita Federal.

Os resultados no que tange as repercussões territoriais, pautados por uma discussão teórica anterior, apresentaram a possibilidade de identificação de padrões no deslocamento dos gastos a partir das categorizações das cadeias produtivas na cultura e das cadeias da cultura, todas alinhadas com as atividades econômicas que realizam. Assim, se notou uma cadeia expressiva nas atividades relacionadas da cultura dentro da região, sobretudo no campo de expressões culturais. Ao mesmo passo, as atividade nucleares tiveram diálogo mais intenso com municípios fora da região, entretanto na mesma cadeia, expressões culturais, se observando assim um padrão nos deslocamentos dos gastos. Identificou-se também um município polo, Santo Ângelo, que concentra os fluxos referentes a gastos públicos municipais em cultura na região das Missões do Rio Grande do Sul. 


\section{REFERÊNCIAS}

ARAÚJO, Tânia Bacelar de. Brasil: desafios de uma Política Nacional de Desenvolvimento Regional contemporânea. In. DINIZ, C. C. (org.). Políticas de Desenvolvimento Regional: desafios e perspectivas à luz das experiências da União Europeia e do Brasil. Brasília: Editora da Universidade, 2007.

BRANDÃO, Carlos. Producción social del ambiente construido y sus escalas espaciales: notas para una teoría acerca de lãs acciones y decisiones de sujetos concretos. In.

FERNÁNDEZ, V. R.; BRANDÃO, C. Escalas y políticas del desarrollo regional: desafíos para America Latina. Buenos Aires/Madrid, Miño e Dávila Editores, 2010. p. 241-272.

CARGNIN, Antônio Paulo. Políticas de desenvolvimento regional no Rio Grande do Sul: vestígios, marcas e repercussões territoriais. Tese de Doutorado - UFRGS, Porto Alegre, 2011.

FURTADO, Celso. O mito do desenvolvimento econômico. Rio de Janeiro: Paz e Terra, 1974.

HOBSBAWM, Eric. Tempos interessantes: uma vida no século XX. São Paulo: Companhia das Letras, 2002.

LEITÃO, Cláudia. Cultura e municipalização. Salvador: Fundação Pedro Calmon, 2009.

MARTINS, Tiago Costa. A alocação de recursos públicos e a possibilidade de configuração de um arranjo produtivo da cultura regional: a Rota Missões no Rio Grande do Sul. São Borja: Ministério da Cultura, 2015. Relatório final de pesquisa.

OLIVEIRA, Francisco de. Elegia para uma re(li)gião: SUDENE, Nordeste. Planejamento e conflito de classes. 3.ed. Rio de Janeiro: Paz e Terra, 1981.

POCHMANN, Marcio. Desenvolvimento e perspectivas novas para o Brasil. São Paulo: Cortez, 2010.

RIBEIRO, M. T. F.; MILANI, C. R. S. (Org.). Compreendendo a complexidade sócio espacial contemporânea: o território como categoria de diálogo interdisciplinar. Salvador: UFBA, 2008.

Artigo recebido em: 14/07/2015

Artigo aprovado em: 02/04/2016 